\title{
Outcome of occupational asthma after removal from exposure: A follow-up study
}

\author{
Catherine Lemiere MD MSc, Simone Chaboillez RT, Mélanie Welman PhD, Karim Maghni DSc PhD
}

\author{
C Lemiere, S Chaboillez, M Welman, K Maghni. Outcome of \\ occupational asthma after removal from exposure: A follow-up \\ study. Can Respir J 2010;17(2):61-66.
}

BACKGROUND: Despite being removed from their workplace, the majority of workers with occupational asthma $(\mathrm{OA})$ remain afflicted with asthma.

OBJECTIVES: To assess the time course of clinical, functional and inflammatory parameters in subjects with $\mathrm{OA}$ over a four-year period, and whether the airway inflammation observed at the time of the diagnosis predicts the outcome of $\mathrm{OA}$.

METHODS: The present study was a four-year, prospective, longitudinal investigation of workers with OA. Spirometry, methacholine challenge and sputum induction were performed at two weeks, and followed up at six months, and one, two, three and four years after the performance of specific inhalation challenges.

RESULTS: A total of 24 subjects were enrolled. Overall, clinical and functional characteristics remained stable during the four-year follow-up period. Sputum eosinophil (Eos) counts decreased within two weeks after exposure. Two groups of subjects were identified according to low (less than $2 \%$, Eos-) or high ( $2 \%$ or greater, Eos + ) Eos counts after exposure to the offending agent. The Eos+ group decreased their dose of inhaled corticosteroids, had a trend toward an improvement of airway responsiveness as well as a stable forced expiratory volume in $1 \mathrm{~s}\left(\mathrm{FEV}_{1}\right)$, whereas the Eosgroup showed a decrease in $\mathrm{FEV}_{1}$, without any improvement in their functional parameters. The Eos- group also had an increase in sputum neutrophils after exposure to the occupational agents as well as during the follow-up period.

CONCLUSION: There was a rapid decrease in eosinophilic inflammation after removal from exposure. Subjects with a noneosinophilic asthmatic reaction during specific inhalation challenge seemed to have a poorer prognosis than subjects with eosinophilic airway inflammation.

Key Words: Eosinophils; Occupational asthma; Sputum cell counts

\section{L'issue de l'asthme professionnel après le retrait de la source d'exposition : Une étude de suivi}

HISTORIQUE : Même s'ils ont quitté leur milieu de travail, la majorité des travailleurs atteints d'asthme professionnel (AP) demeurent affligés par l'asthme.

OBJECTIFS : Évaluer le cours chronologique des paramètres cliniques, fonctionnels et inflammatoires chez des sujets atteints d'AP sur une période de quatre ans et si l'inflammation des voies respiratoires observées au moment du diagnostic permet de prédire l'issue de l'AP.

MÉTHODOLOGIE : La présente étude consistait en une exploration longitudinale prospective de travailleurs atteints d'AP. On leur a fait subir une spirométrie, une épreuve à la méthacholine et une induction de l'expectoration deux semaines, six mois, puis, un, deux, trois et quatre ans après l'exécution d'épreuves d'inhalation précises.

RÉSULTATS : Au total, 24 sujets ont participé à l'étude. Dans l'ensemble, leurs caractéristiques cliniques et fonctionnelles sont demeurées stables pendant la période de suivi de quatre ans. La numération des éosinophiles (Éos) de l'expectoration avait diminué deux semaines après l'exposition. On a repéré deux groupes de sujets d'après leur numération d'Éos faible (inférieure à $2 \%$, Éos-) ou élevée (2\% ou plus, Éos+) après l'exposition à l'agent offensant. Le groupe Éos+ a réduit sa dose de corticoïdes en aérosol, présentait une tendance vers l'amélioration de la réactivité des voies respiratoires et un volume expiratoire maximal par seconde (VEMS) stable, tandis que le groupe Éos- affichait une diminution du VEMS, sans améliorations des paramètres fonctionnels. Le groupe Éos- présentait également une augmentation des neutrophiles d'expectoration après l'exposition aux agents professionnels et pendant la période de suivi.

CONCLUSION : On a constaté une diminution rapide de l'inflammation à éosinophiles après le retrait de l'exposition. Les sujets ayant une réaction asthmatique non éosinophile pendant l'épreuve d'inhalation précise semblaient présenter un pronostic plus négatif que ceux atteints d'une inflammation à éosinophiles des voies respiratoires.

Asthma tends to be considered a syndrome comprised of different phenotypes rather than as a disease representing a homogeneous group of patients (6). Indeed, different phenotypic categories have been reported according to clinical or inflammatory characteristics, or the triggers inducing or aggravating asthma (7). Eosinophilic and noneosinophilic phenotypes have been described. Approximately $30 \%$ to $50 \%$ of asthma cases seem to be noneosinophilic $(8,9)$; however, little is known about the prognosis of these phenotypes. One study (10) reported that subjects with $\mathrm{OA}$ who showed an eosinophilic airway inflammation three to 39 months after removal from exposure tended to have a smaller improvement in their airway responsiveness than subjects without eosinophilic inflammation. Whether the type of airway inflammation induced by acute exposure to the occupational agent can be associated with a different outcome is unknown. ies included.

Department of Chest Medicine, Sacré-Coeur Hospital, University of Montreal, Montreal, Quebec

Correspondence: Dr Catherine Lemiere, Department of Chest Medicine, Sacré-Coeur Hospital, 5400 Gouin West, Montreal, Quebec H4J 1 C5.

Telephone 514-338-2796, fax 514-338-3123, e-mail catherine.lemiere@umontreal.ca 
We sought to assess the time course of clinical, functional and inflammatory parameters in subjects with OA over a fouryear period, and whether the type of airway inflammation (eosinophilic versus noneosinophilic) induced by acute exposure to occupational agents was associated with a different outcome of OA.

\section{Subjects}

All subjects investigated at Sacré-Coeur Hospital (Montreal, Quebec) for OA who were positive for specific inhalation challenge (SIC) between November 2001 and August 2003, and agreed to participate in the present study were enrolled. The study was approved by Sacré-Coeur Hospital's Research Ethics Committee. All subjects gave their written informed consent.

\section{Study design}

The present investigation was a four-year, prospective, longitudinal study undertaken between November 2001 and August 2007. The recruitment was completed during the first two years; all subjects underwent a four-year follow-up. A sputum induction and a methacholine inhalation challenge were performed before and after the SICs. Six visits were scheduled: at two weeks, six months, one, two, three and four years after the SICs. During each visit, respiratory symptoms and asthma quality of life were assessed, and spirometry, methacholine challenge and sputum induction were performed. Asthma treatment was documented. At each follow-up visit, the subjects were assessed by a chest physician and treatment was modified according to the Canadian Asthma Guidelines (11). Blood was also drawn to measure interleukin (IL) -5 and interferongamma (IFN- $\gamma$ ) expression in peripheral blood leukocytes.

\section{Procedures}

Questionnaires: Respiratory symptoms (dyspnea, cough, sputum production, chest tightness and wheezing) were scored according to a validated 10-point Borg scale from 0 (no symptoms) to 10 (worst symptoms) (12). The asthma quality of life was assessed using a validated questionnaire (13).

Respiratory function tests: At the initial assessment, spirometry was assessed according to the standards of the American Thoracic Society (14). The methacholine challenge was performed as previously described (15) using a Wright's nebulizer (output $0.14 \mathrm{~mL} / \mathrm{min}$ ) at tidal volumes for $2 \mathrm{~min}$.

Sputum induction and processing: Sputum was induced using inhalations of increasing concentrations (3\%, 4\% and 5\%) of hypertonic saline (16) and processed as previously described (17).

\section{Quantification of IL-5 and IFN- $\gamma$ expression in peripheral blood leukocytes}

Blood samples were mixed with a dextran solution and peripheral blood leukocytes (PBL) were isolated by centrifugation of the mixture. Total RNAs were extracted using the TRIZOL (Invitrogen Canada Inc) reagent and reverse transcription of messenger RNAs were performed to produce complimentary DNA (cDNA) as previously described (18). cDNA was amplified by conventional polymerase chain reaction (PCR) (18), purified, quantified and used to construct reference standard curves for gene quantification by real-time PCR using the LightCycler system (Roche Diagnostics Canada). Briefly, PCR reactions were performed in a total volume of $20 \mu \mathrm{L}$ containing
$2 \mu \mathrm{L}$ of cDNA, $20 \mu \mathrm{M}$ of each primer, $3 \mathrm{mM} \mathrm{MgCl}_{2}$ and $2 \mu \mathrm{L}$ of SYBR Green fluorescent dye (Roche Diagnostics Canada). The same primers were used for conventional and real-time PCR, and amplified across exon-intron boundaries to allow discrimination between genomic DNA and cDNA sequences. The PCR protocol consisted of denaturation at $95^{\circ} \mathrm{C}$ for 10 min, followed by 40 PCR amplification cycles of annealing at $56^{\circ} \mathrm{C}($ IFN- $\gamma), 68^{\circ} \mathrm{C}\left(\right.$ IL-5) or $55^{\circ} \mathrm{C}$ (ribosome S9) for $10 \mathrm{~s}$ and extension at $72^{\circ} \mathrm{C}$ for $17 \mathrm{~s}($ IFN- $\gamma$ ), $20 \mathrm{~s}$ (IL-5) or $10 \mathrm{~s}$ (ribosome S9). Concentrations of target cDNA were calculated relative to their respective standard curves by melting curve analysis. Absence of primer-dimer formation was determined by studying the melting curves of the final PCR amplicons, obtained by slowly heating from $70^{\circ} \mathrm{C}$ to $95^{\circ} \mathrm{C}$, with fluorescence detection every $0.2^{\circ} \mathrm{C}$. The data were analyzed using RelQuant software (Roche Diagnostics Canada) and expressed as the ratio (gene of interest/S9 gene) $\times 1000$.

\section{Skin-prick tests}

Subjects underwent skin-prick tests with an array of 14 common inhalant allergens (19). A subject was considered to be atopic by the presence of at least one positive skin test with a wheal diameter of $3 \mathrm{~mm}$ or greater.

\section{SICs}

SICs were performed as previously described (20) in the laboratory or at the workplace. On the first day, subjects were exposed to a control substance (lactose for subjects exposed to particles or a paint thinner (Varsol, ExxonMobil, USA) for subjects exposed to chemicals) for $30 \mathrm{~min}$ to ensure that their asthma was stable. On subsequent days, they were progressively exposed to the occupational agent suspected of causing their asthma. When the challenge was negative in the laboratory or when the workplace exposure could not be reproduced in the laboratory, the subjects were returned to their workplace under the supervision of a respiratory technologist, who assessed their respiratory function hourly over $7 \mathrm{~h}$ on two consecutive days. A SIC was considered positive if there was a fall in forced expiratory volume in $1 \mathrm{~s}\left(\mathrm{FEV}_{1}\right)$ of $20 \%$. A methacholine challenge was performed at the end of the control day and on the last day of exposure. Long-acting beta- 2 agonists were interrupted $72 \mathrm{~h}$ before the challenge. Inhaled corticosteroids (ICS) were continued during the challenge, but the total daily dose was administered $12 \mathrm{~h}$ before the challenge.

\section{Data analysis}

Normally distributed data were expressed as mean \pm SD. Nonnormally distributed data were expressed as median and interquartile range (IQR). The changes over time observed within subjects were compared using an ANOVA for repeated measures. Two groups of subjects were identified according to the per cent sputum eosinophil counts (Eos) after exposure to the offending agent during SIC. Subjects were defined as Eos- if Eos were less than 2\%, and Eos+ if Eos were 2\% or greater.

Differences between eosinophilic and noneosinophilic subjects were compared using the Student's $t$ test or the Mann Whitney test, as appropriate. Correlations between variables were studied using the Pearson's test or the Spearman's rank test depending on whether the data were normally distributed. $\mathrm{P}<0.05$ was considered to be statistically significant. The analysis was performed using SPSS (SPSS Inc, USA). 


\section{RESULTS}

A total of 24 subjects diagnosed with OA using SICs were enrolled. Five subjects were lost to follow-up. Nineteen subjects completed the four-year follow-up, none of whom were re-exposed to the occupational agent that caused their asthma.

Characteristics of the subjects at the time of diagnosis

Five women and 19 men were enrolled. Thirteen subjects had OA due to high-molecular-weight agents and 11 due to lowmolecular-weight agents. At the time of the SIC, 15 subjects were still exposed to their offending agent and nine had been removed from exposure for a mean of $4.0 \pm 2.8$ months. After the positive SIC, all subjects were removed from exposure. The characteristics of these subjects are presented in Table 1.

Outcome of the study subjects after removal from exposure Overall, the clinical characteristics (symptom score, asthma quality of life and rescue use of short-acting beta-2 agonists) remained stable during the four-year follow-up. There was no significant improvement in the clinical parameters (Table 2).

The majority of subjects ceased their ICS treatment during the follow-up period. Indeed, only eight subjects were still on ICS after four years compared with 17 at the time of the diagnosis. The mean dose of ICS also decreased with time from $736.8 \pm 562.0 \mu \mathrm{g} /$ day at baseline to $294.7 \pm 529.8 \mu \mathrm{g} / \mathrm{day}$ $(\mathrm{P}=0.009)$ four years later.

No significant correlation was found between the duration of exposure after the occurrence of respiratory symptoms and the change in $\mathrm{FEV}_{1}(\mathrm{r}=0.02, \mathrm{P}=0.9)$ and provocative concentration of methacholine causing a $20 \%$ fall in $\mathrm{FEV}_{1}\left(\mathrm{PC}_{20}\right)$ $(\mathrm{r}=-0.05 ; \mathrm{P}=0.9)$ between baseline and three years postexposure. Smoking was not associated with either a change in $\mathrm{FEV}_{1}(\mathrm{P}=0.3)$ or $\mathrm{PC}_{20}(\mathrm{P}=0.4)$.

There was a slight but significant overall improvement in $\mathrm{PC}_{20}$ over the four-year follow-up period $(\mathrm{F}=2.6, \mathrm{P}=0.03)$. Four years after removal from exposure, seven subjects showed an improvement in their airway responsiveness of at least two doubling dilutions, whereas 10 subjects did not show any change. The subjects who did not show any improvement in their $\mathrm{PC}_{20}$ did not show a higher sputum eosinophil count $(0.25 \%$ [2.63]) than those who had improved their airway responsiveness $(1.8 \%[2.8] ; \mathrm{P}=0.08)$. However, there was an inverse correlation between Eos counts and $\mathrm{PC}_{20}(\mathrm{r}=-0.6, \mathrm{P}=0.004)$ three years after removal from
TABLE 1

Characteristics of the study subjects $(n=24)$

\begin{tabular}{|c|c|}
\hline Age, years (mean $\pm S D$ ) & $37.6 \pm 11.3$ \\
\hline Sex, male/female & $19 / 5$ \\
\hline Atopy & 22 \\
\hline \multicolumn{2}{|l|}{ Smoking habits } \\
\hline Ex smoker & 8 \\
\hline Nonsmoker & 10 \\
\hline Current smoker & 6 \\
\hline Duration of exposure, years (mean $\pm S D$ ) & $13.2 \pm 11.0$ \\
\hline $\begin{array}{l}\text { Duration of exposure after onset of } \\
\text { respiratory symptoms, years (mean } \pm \mathrm{SD} \text { ) }\end{array}$ & $4.4 \pm 5.8$ \\
\hline Agents, low molecular weight/high molecular weight & $11 / 13$ \\
\hline \multicolumn{2}{|l|}{ Low molecular weight } \\
\hline Isocyanates & 7 \\
\hline Polyethylene & 1 \\
\hline Red cedar & 1 \\
\hline Persulfate & 1 \\
\hline Nonidentified agent (SIC at the workplace) & 1 \\
\hline \multicolumn{2}{|l|}{ High molecular weight } \\
\hline Flour & 6 \\
\hline Grain & 1 \\
\hline Liquorice & 1 \\
\hline Chicken & 1 \\
\hline Casein & 1 \\
\hline Cat & 1 \\
\hline Pork & 1 \\
\hline Latex & 1 \\
\hline \multicolumn{2}{|l|}{ Reaction types } \\
\hline Immediate & 20 \\
\hline Late & 3 \\
\hline Dual & 1 \\
\hline
\end{tabular}

Data presented as $n$ unless indicated otherwise. SIC Specific inhalation challenge

exposure. Only four subjects did not show airway hyperresponsiveness four years after the diagnosis.

The Eos counts decreased rapidly in the vast majority of subjects. Indeed, only nine subjects had an Eos count higher than $2 \%$ two weeks after the SIC, compared with 15 at the time of the SIC. At the four-year follow-up, only four subjects still showed an Eos count of greater than 2\% (Table 2).

TABLE 2

Outcome of functional and inflammatory parameters during the study period

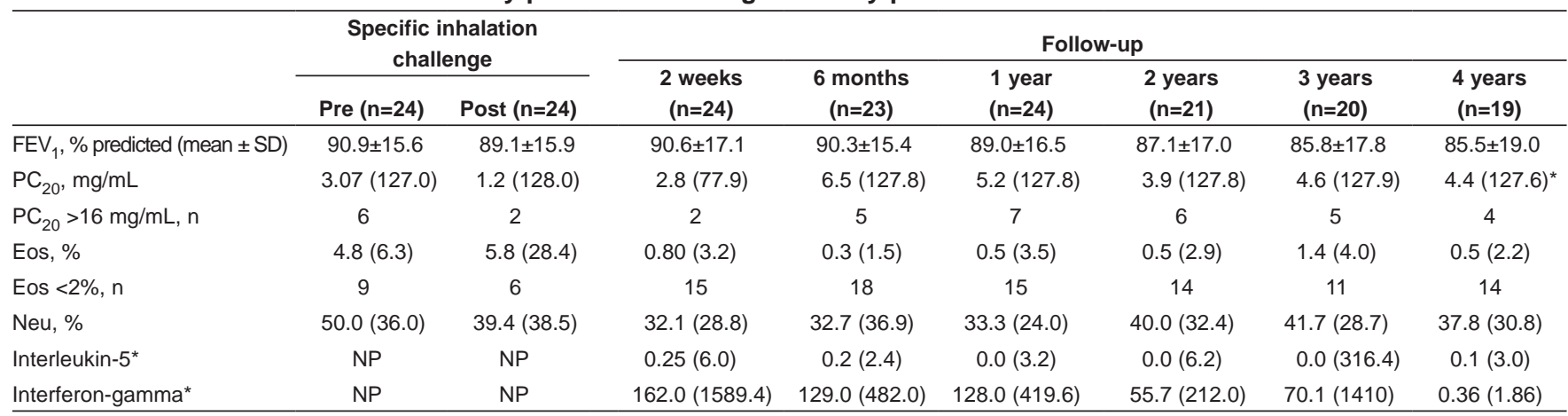

Data presented as median (interquartile range [IQR]) unless indicated otherwise. *Interleukin 5 and Interferon-gamma are expressed as the median (IQR) ratio (gene of interest/S9gene) $\times 1000$. Eos Sputum eosinophil count; FEV ${ }_{1}$ Forced expiratory volume in $1 \mathrm{~s}$; Neu Sputum neutrophil count; NP Not performed; PC 20 Provocative concentration of methacholine causing a $20 \%$ fall in $F E V_{1}$ 


\begin{tabular}{|c|c|c|c|}
\hline & Eos- (Eos <2\%) & Eos+ ( Eos $\geq 2 \%$ ) & $\mathbf{P}$ \\
\hline $\mathrm{n}$ & 7 & 15 & \\
\hline Age, years & $34.3 \pm 10.8$ & $38.9 \pm 10.5$ & 0.3 \\
\hline Sex, male/female & $4 / 3$ & $13 / 2$ & 0.3 \\
\hline Smoking habits, $\mathrm{n}$ & & & 0.4 \\
\hline Nonsmoker & 1 & 6 & \\
\hline Ex smoker & 4 & 5 & \\
\hline Current smoker & 2 & 4 & \\
\hline Atopy, n & 6 & 14 & 0.5 \\
\hline $\begin{array}{l}\text { Duration of removal from } \\
\text { exposure before SIC, } \\
\text { months }\end{array}$ & $1.3 \pm 1.9$ & $1.1 \pm 2.3$ & 0.8 \\
\hline $\begin{array}{l}\text { Duration of exposure after } \\
\text { occurrence of symptoms, } \\
\text { years }\end{array}$ & $3.5 \pm 3.8$ & $4.8 \pm 7.0$ & 0.6 \\
\hline ICS dose, $\mu \mathrm{g}$ & $857.1 \pm 377.9$ & $800 \pm 676.2$ & 0.8 \\
\hline Occupational agent, n & & & 0.5 \\
\hline High molecular weight & 4 & 7 & \\
\hline Low molecular weight & 3 & 8 & \\
\hline Reaction type, $\mathrm{n}$ & & & 0.5 \\
\hline Immediate & 5 & 14 & \\
\hline Dual & 0 & 1 & \\
\hline Late & 2 & 0 & \\
\hline
\end{tabular}

Data presented as mean \pm SD unless indicated otherwise. ICS Inhaled corticosteroid

The median levels of IL-5 were slightly, but significantly lower four years after the diagnosis $(0.1$, IQR 3.0) compared with the time of the diagnosis $(0.25$, IQR 6.0; $\mathrm{P}=0.03)$. Median levels of IFN- $\gamma$ decreased significantly four years after the diagnosis $(0.36, \mathrm{IQR} 1.86)$ compared with the time of the diagnosis (162.0, IQR 1589.4) $(\mathrm{P}=0.005)$.

\section{Outcome of subjects according to the type of airway inflammation induced by acute exposure to the offending agent}

Two groups of subjects were identified according to the per cent Eos counts following exposure to the offending agent during SICs: Eos- (less than $2 \%, n=7$ ) median Eos count $0.8 \%$ (IQR 0.8); Eos+ ( $2 \%$ or greater, $\mathrm{n}=15$ ) median Eos count $17.3 \%$ (IQR 26.0). The baseline characteristics of the Eos- and Eos+ groups were similar (Table 3).

There was no difference between the daily dose of ICS, the number of subjects taking ICS, or the duration of removal from exposure before SICs between the Eos+ and Eos- groups (Table 3). There was a significant increase in median sputum neutrophils after SIC (64.2\%, IQR 51.3) compared with the control day $(50.2$, IQR 35.5; P =0.04) in the Eos- group only. In contrast, there was no increase in sputum neutrophils between the control day (45.9\%, IQR 42.5) and after exposure $(36.8 \%$, IQR 29.5) in the Eos+ group ( $\mathrm{P}=0.7)$ (Tables 4 and 5). There was also a higher sputum neutrophil count in the Eos- group four years after removal from exposure than in the Eos+ group $(\mathrm{P}=0.048)$.

The Eos- group showed a significant decrease in their $\mathrm{FEV}_{1}$ three and four years after exposure compared with the baseline $(\mathrm{P}=0.04)$ in contrast with the Eos+ group (Table 4). The Eos+ group significantly decreased their dose of ICS $(\mathrm{P}=0.04)$ without increasing the use of their short-acting beta- 2 agonists, which was not the case in the Eos- group. There was a trend toward an improvement of airway responsiveness in the Eos+ group, which was not observed in the Eos-group. Furthermore, all subjects who normalized their airway responsiveness belonged to the Eos+ group (Table 5).

\section{DISCUSSION}

The present study showed a rapid decrease in eosinophilic airway inflammation followed by an improvement of airway responsiveness, which occurred mainly in the first six months after the removal from exposure to a variety of occupational agents in workers with OA. However, there was not a consistent improvement in the clinical and functional parameters in the population studied. Indeed, we identified a noneosinophilic phenotype that showed a significant decline in their $\mathrm{FEV}_{1}$, along with a lack of improvement in the airway responsiveness during the four-year follow-up period. In contrast, the eosinophilic phenotype showed no $\mathrm{FEV}_{1}$ alteration over time, showed a significant decrease in ICS doses as well as a trend toward an improvement in airway responsiveness during the follow-up period.

To our knowledge, this is the first prospective, longitudinal study designed to assess the functional and inflammatory parameters of subjects with $\mathrm{OA}$ during four years after removal from exposure. The previous studies that examined the outcome of workers were mainly cross-sectional and did not include a continuous follow-up after the diagnosis (2).

The duration of exposure after the occurrence of the respiratory symptoms have often been described as a prognostic factor for OA. However, we could not find any correlation between the magnitude of improvement of the functional parameters and the duration of exposure after the occurrence of respiratory symptoms. Although our study may not have been adequately powered to demonstrate such a relationship, a recent systematic review (3) also failed to identify this parameter as a prognostic factor for OA. Furthermore, smoking did not appear to modify the prognosis of our subjects.

The proportion of subjects who continued to have eosinophilic inflammation even after removal from exposure was similar to what we found in a larger population in which only $17.8 \%$ of subjects showed airway inflammation 10 years after removal from exposure (21). However, in this previous study, the Eos count was not studied at the time of the diagnosis.

We were able to detect significant changes in IL-5 and IFN- $\gamma$ expressions in blood lymphocytes over time after removal from exposure. Indeed, there was an important decrease in the IFN- $\gamma$ expression four years after removal from exposure compared with the baseline. The role of IFN- $\gamma$ in asthma pathogenesis is still unclear. INF- $\gamma$ has been shown to promote an antiinflammatory effect on allergic inflammation $(22,23)$, as well as an inhibitory effect on airway hyper-responsiveness (23). In contrast, other reports (24) indicate that blocking IFN- $\gamma$ actions results in the inhibition of airway hyperresponsiveness. Therefore, the production of IFN- $\gamma$ is likely to have a regulatory effect after the occurrence of an asthmatic reaction in humans. Although we did not observe high levels of IL-5 two weeks after removal from exposure, IL-5 also decreased over time. Because the first sampling was performed two weeks after 


\begin{tabular}{|c|c|c|c|c|c|}
\hline & \multicolumn{5}{|c|}{ Eos- $(<2 \%)$} \\
\hline & \multicolumn{2}{|c|}{ Specific inhalation challenge } & \multicolumn{3}{|c|}{ Follow-up } \\
\hline & Pre $(n=7)$ & Post $(n=7)$ & 2 weeks $(n=7)$ & 3 years $(n=6)$ & 4 years $(n=5)$ \\
\hline Symptoms, mean \pm SD & NP & NP & $5.1 \pm 1.3$ & $5.1 \pm 1.7$ & $5.2 \pm 1.5$ \\
\hline Quality of life score, mean \pm SD & NP & NP & $5.1 \pm 1.07$ & $5.1 \pm 1.8$ & $5.4 \pm 1.4$ \\
\hline Daily dose of short-acting beta-2 agonists, mean \pm SD & NP & NP & $0.5 \pm 0.7$ & $0.5 \pm 0.8$ & $0.07 \pm 0.07$ \\
\hline Inhaled corticosteroid dose, $\mu \mathrm{g}$ (mean $\pm \mathrm{SD}$ ) & $857.1 \pm 378.0$ & $857.1 \pm 378.0$ & $857.1 \pm 378.0$ & $1250.0 \pm 880.3$ & $416.6 \pm 801.1$ \\
\hline Subjects taking inhaled corticosteroids, $\mathrm{n}$ & 6 & 6 & 6 & 5 & 2 \\
\hline Daily inhaled corticosteroid dose ${ }^{*}, \mu \mathrm{g}($ mean $\pm \mathrm{SD})$ & $1000.0 \pm 0$ & $1000.0 \pm 0$ & $1000.0 \pm 0$ & $1500.0 \pm 707.1$ & $1250.0 \pm 1060.6$ \\
\hline Forced expiratory volume in $1 \mathrm{~s}, \%$ predicted (mean \pm SD) & $88.6 \pm 18.7$ & $87.3 \pm 20.4$ & $89.5 \pm 19.7$ & $80.5 \pm 19.4$ & $81.3 \pm 20.3^{\dagger}$ \\
\hline $\mathrm{PC}_{20}, \mathrm{mg} / \mathrm{mL}$ (median [IQR]) & $1.6(15.5)$ & $0.71(3.0)$ & $1.3(15.8)$ & $1.2(5.3)$ & $1.5(7.6)$ \\
\hline $\mathrm{PC}_{20}>16 \mathrm{mg} / \mathrm{L}, \mathrm{n}$ & 0 & 0 & 0 & 0 & 0 \\
\hline Sputum eosinophils, \% (median [IQR]) & $1.0(5.1)$ & $0.8(0.8)$ & $0.0(0.3)$ & $4.2(10.5)$ & $0.5(4.0)$ \\
\hline Sputum neutrophils, \% (median [IQR]) & $50.2(35.5)$ & $64.2(51.3)$ & $30.3(30.2)$ & $53.3(22.3)$ & $48.7(23.3)$ \\
\hline Interleukin-5 $5^{\ddagger}$, median (IQR) & NP & NP & $0.0(1.2)$ & - & $1.5(5.7)$ \\
\hline Interferon-gamma ${ }^{\ddagger}$, median (IQR) & NP & NP & 919.5 (3708.0) & - & $0.23(33.04)$ \\
\hline
\end{tabular}

${ }^{\star}$ Daily dose of inhaled corticosteroids in subjects who were taking inhaled corticosteroids; ${ }^{\dagger} P \leq 0.05$; ${ }^{\ddagger}$ Interleukin-5 and Interferon-gamma are expressed as the ratio (gene of interest/S9gene) $\times 1000$. IQR Interquartile range; NP Not performed; $P C_{20}$ Provocative concentration of methacholine causing a $20 \%$ fall in forced expiratory volume in $1 \mathrm{~s}$

TABLE 5

Outcome of subjects with high sputum eosinophil (Eos+) counts after specific inhalation challenge

\begin{tabular}{|c|c|c|c|c|c|}
\hline & \multicolumn{5}{|c|}{ Eos+ $(\geq 2 \%)$} \\
\hline & \multicolumn{2}{|c|}{ Specific inhalation challenge } & \multicolumn{3}{|c|}{ Follow-up } \\
\hline & Pre (n=15) & Post $(n=15)$ & 2 weeks $(n=15)$ & 3 years $(n=13)$ & 4 years $(n=12)$ \\
\hline Symptoms, mean \pm SD & NP & NP & $5.4 \pm 1.3$ & $5.6 \pm 1.6$ & $5.7 \pm 1.1$ \\
\hline Quality of life score, mean \pm SD & NP & NP & $5.5 \pm 1.3$ & $5.6 \pm 1.5$ & $5.7 \pm 1.0$ \\
\hline Daily dose of short-acting beta- 2 agonists, mean \pm SD & NP & NP & $0.3 \pm 0.8$ & $0.8 \pm 2.0$ & $0.7 \pm 1.9$ \\
\hline Inhaled corticosteroid dose, $\mu \mathrm{g}$ (mean $\pm \mathrm{SD}$ ) & $800.0 \pm 676.1$ & $800.0 \pm 676.1$ & $800.0 \pm 676.1$ & $288.5 \pm 593.8$ & $175.0 \pm 314.2^{*}$ \\
\hline Subjects taking inhaled corticosteroids, $\mathrm{n}$ & 10 & 10 & 10 & 4 & 5 \\
\hline Daily inhaled corticosteroid dose ${ }^{\dagger}, \mu \mathrm{g}$ (mean \pm SD) & $1200.0 \pm 421.6$ & $1200.0 \pm 421.6$ & $1200.0 \pm 421.6$ & $937.5 \pm 773.9$ & $420.0 \pm 378.1$ \\
\hline Forced expiratory volume in $1 \mathrm{~s}, \%$ predicted (mean $\pm \mathrm{SD}$ ) & $92.8 \pm 14.7$ & $90.7 \pm 14.0$ & $91.9 \pm 16.8$ & $89.9 \pm 16.7$ & $89.2 \pm 18.6$ \\
\hline $\mathrm{PC}_{20}, \mathrm{mg} / \mathrm{mL}($ median $[\mathrm{IQR}])$ & $4.4(127.9)$ & $1.57(128)$ & $4.1(77.9)$ & $9.9(127.9)$ & $9.0(127.6)$ \\
\hline $\mathrm{PC}_{20}>16 \mathrm{mg} / \mathrm{L}, \mathrm{n}$ & 5 & 2 & 2 & 5 & 4 \\
\hline Sputum eosinophils, \% (median [IQR]) & $5.4(7.1)$ & $17.3(26.0)$ & $2.5(3.8)$ & $1.2(3.0)$ & $0.5(1.8)$ \\
\hline Sputum neutrophils, \% (median [IQR]) & $45.9(42.5)$ & $36.8(29.5)$ & $34.0(26.4)$ & $37.5(27.7)$ & $29.6(28.5)$ \\
\hline Interleukin-5 $5^{\ddagger}$, median (IQR) & - & - & $4.0(15.0)$ & - & $0.3(7.7)$ \\
\hline Interferon-gamma ${ }^{\ddagger}$, median (IQR) & - & - & $113.3(951.3)$ & - & $0.38(2.86)$ \\
\hline
\end{tabular}

${ }^{*} P \leq 0.05 ;{ }^{\dagger}$ Daily dose of inhaled corticosteroids in subjects who were taking inhaled corticosteroids; ${ }^{\ddagger}$ Interleukin-5 and interferon-gamma are expressed as the ratio (gene of interest/S9gene) $\times 1000$. IQR Interquartile range; NP Not performed; $P C_{20}$ Provocative concentration of methacholine causing a $20 \%$ fall in forced expiratory volume in $1 \mathrm{~s}$

exposure to the offending agent, we may have missed an early increase in IL-5.

Evidence suggests that noneosinophilic asthma is a distinct phenotype. Treatment with ICS does not seem to have the same efficacy in noneosinophilic asthma compared with eosinophilic asthma $(25,26)$. Some authors have suggested that the lack of eosinophilic inflammation maybe a characteristic of refractory asthma (25). The lack of sputum eosinophilia after exposure to occupational agents may also be an indicator of a poor prognosis. Indeed, in contrast to the subjects showing sputum eosinophilia after SIC, the subjects who did not show an eosinophilic inflammation at baseline had a decline in their $\mathrm{FEV}_{1}$ over time and did not show any improvement of their airway hyperresponsiveness. Neutrophilic inflammation is also likely to play an important role in asthma. Indeed, several authors have demonstrated a relationship between airway neutrophilia and persistent airflow limitation in asthma
$(27,28)$. Douwes et al $(9)$ suggested that most noneosinophilic asthma may be neutrophil mediated. This hypothesis is supported by our data showing an increase in sputum neutrophilia after SIC only in the Eos- group. The decline in $\mathrm{FEV}_{1}$ observed over time in the Eos- group may be related to a marked remodelling process in this group. Matrix metalloproteinases play a role in matrix turnover, which may be an important factor in airway remodelling. Because neutrophils are the main source of matrix metalloproteinases- 9 and -8 in the lung $(29,30)$, it may be possible that a neutrophilic inflammation induces a greater remodelling process than an eosinophilic inflammation.

The potential triggers orienting the type of airway inflammation toward an eosinophilic or a noneosinophilic type during exposure to occupational agents are unclear. In the present study, the type of occupational agents to which the workers with eosinophilic or noneosinophilic phenotypes were exposed were similar. 
ICS have been shown to suppress eosinophilic airway inflammation very effectively (31). Therefore, it may be argued that the low per cent of Eos counts demonstrated by the Eosgroup may be due to treatment with higher ICS doses than in the Eos+ group. However, when SICs were performed, the Eosgroup included the same number of subjects treated with a similar dose of ICS as the Eos+ group. Furthermore, the delay between the removal from exposure and the performance of the SIC was similar in both groups.

The main limitation of our study is the small sample size, which prevented us from performing multivariate analyses to take into account confounding factors. However, we tried to specifically address some known confounding factors in the analysis, such as treatment with ICS and duration of the removal from exposure. Therefore, our findings raise a challenging hypothesis in which different mechanisms of asthmatic reactions may lead to different outcomes of the disease.

\section{CONCLUSION}

Functional and inflammatory parameters improve mainly within the first six months after removal from exposure to an occupational sensitizing agent. Workers with a noneosinophilic phenotype of OA seemed to have a poorer prognosis than workers with an eosinophilic phenotype. These results need to be confirmed through further studies with larger sample sizes to investigate the determinants of an eosinophilic or a noneosinophilic response.

ACKNOWLEDGEMENTS: The authors thank Dr James G Martin and $\mathrm{Mr}$ James Hatch for reviewing the manuscript. Dr Lemiere was responsible for conducting the study and writing the manuscript. Mrs Chaboillez was responsible for the recruitment of the subjects, performing the respiratory function tests and sputum processing. Dr Welman was responsible for performing the quantification of cytokine expressions. Dr Maghni supervised the quantification of cytokine expressions and participated to the writing of the manuscript. Dr C Lemiere holds a scholarship from the Fonds de la Recherche en Santé du Québec.

FUNDING: Institut de Recherche Robert Sauvé en Santé et Sécurité au Travail.

\section{REFERENCES}

1. Bernstein I, Bernstein D, Chan-Yeung M, Malo J. Definition and classification of asthma in the workplace. In: Bernstein IL, ChanYeung M, Malo JL, Bernstein DI, eds. Asthma in the Workplace, 3rd edn, New York: Taylor \& Francis, 2006:1-8.

2. Perfetti L, Cartier A, Ghezzo H, Gautrin D, Malo J.

Follow-up of occupational asthma after removal from or diminution of exposure to the responsible agent: Relevance of the length of the interval from cessation of exposure. Chest 1998;114:398-403.

3. Rachiotis G, Savani R, Brant A, et al. Outcome of occupational asthma after cessation of exposure: A systematic review. Thorax 2007;62:147-52.

4. Chan-Yeung M, MacLean L, Paggiaro P. Follow-up study of 232 patients with occupational asthma caused by western red cedar (Thyja plicata). J Allergy Clin Immunol 1987;79:792-6.

5. Descatha A, Leproust H, Choudat D, Garnier R, Pairon J, Ameille J. Factors associated with severity of occupational asthma with a latency period at diagnosis. Allergy 2007;62:795-801.

6. Bel EH. Clinical phenotypes of asthma. Curr Opin Pulm Med 2004;10:44-50.

7. Wenzel SE. Asthma: Defining of the persistent adult phenotypes. Lancet 2006;368:804-13.
8. Turner M, Hussack P, Sears M, Dolovich J, Hargreave F. Exacerbations of asthma without sputum eosinophilia. Thorax 1995;50:1057-61.

9. Douwes J, Gibson P, Pekkanen J, Pearce N. Non-eosinophilic asthma: Importance and possible mechanisms. Thorax 2002;57:643-8.

10. Paggiaro P, Bacci E, Dente F, et al. Bronchoalveolar lavage and morphology of the airways after cessation of exposure in asthmatic subjects sensitized to toluene diisocyanate. Chest 1990;98:536-42.

11. Lemiere C, Bai T, Balter M, et al. Adult asthma consensus guidelines update 2003. Can Respir J 2004;11(Suppl A):9A-18A.

12. Borg G. Ratings of perceived exertion and heart rates during short-term cycle exercise and their use in a new cycling strength test. Int J Sports Med 1982;3:153-8.

13. Juniper E, Buist A, Cox F, Ferrie P, King DR. Validation of a standardized version of the asthma quality of life questionnaire. Chest 1999;115:1265-70.

14. Society AT. Standardization of spirometry. Am J Respir Crit Care Med 1995;152:1107-36.

15. Juniper E, Cockcroft D, Hargreave F. Histamine and Methacholine Inhalation Tests, 2nd edn. Lund: Canadian Thoracic Society and Astra Draco AB, 1994.

16. Pin I, Gibson P, Kolendowicz F, et al. Use of induced sputum cell counts to investigate airway inflammation in asthma. Thorax 1992;47:25-9.

17. Pizzichini E, Pizzichini M, Efthimiadis A, Dolovich J, Hargreave F. Measuring airway inflammation in asthma: Eosinophils and eosinophilic cationic protein in induced sputum compared with peripheral blood. J Allergy Clin Immunol 1997;99:539-44.

18. Maghni K, Taha R, Afif W, Hamid Q, Martin J. Dichotomy between neurokinin receptor actions in modulating allergic airway responses in an animal model of helper T cell type 2 cytokineassociated inflammation. Am J Respir Crit Care Med 2000;162:1068-74.

19. Perrin L, Dechamp C, Deviller P, Joly P. Reproducibility of skin tests. A comparative study of the Pepys prick test and the MorrowBrown needle and their correlation with the serum IgE level. Clin Allergy 1984;14:581-8.

20. Cartier A. Definition and diagnosis of occupational asthma. Eur Respir J 1994;7:153-60.

21. Maghni K, Lemière C, Ghezzo H, Yuquan W, Malo J. Airway inflammation after cessation of exposure to agents causing occupational asthma. Am J Respir Crit Care Med 2004;169:367-72.

22. Nakamura T, Lee RK, Nam SY, Podack ER, Bottomly K, Flavell RA. Roles of IL-4 and IFN-gamma in stabilizing the T helper cell type 1 and 2 phenotype. J Immunol 1997;158:2648-53.

23. Hofstra CL, Van Ark I, Hofman G, Nijkamp FP, Jardieu PM, Van Oosterhout AJ. Differential effects of endogenous and exogenous interferon-gamma on immunoglobulin E, cellular infiltration, and airway responsiveness in a murine model of allergic asthma. Am J Respir Cell Mol Biol 1998;19:826-35.

24. Kumar RK, Herbert C, Webb DC, Li L, Foster PS. Effects of anticytokine therapy in a mouse model of chronic asthma. Am J Respir Crit Care Med 2004;170:1043-8.

25. Pavord I, Brighting C, Woltmann G, Wardlaw A. Non-eosinophilic corticosteroid unresponsive asthma. Lancet 1999;353:2213-4.

26. Szefler SJ, Martin RJ, King TS, et al. Significant variability in response to inhaled corticosteroids for persistent asthma. J Allergy Clin Immunol 2002;109:410-8.

27. Woodruff PG, Khashayar R, Lazarus SC, et al. Relationship between airway inflammation, hyperresponsiveness, and obstruction in asthma. J Allergy Clin Immunol 2001;108:753-8.

28. Shaw DE, Berry MA, Hargadon B, et al. Association between neutrophilic airway inflammation and airflow limitation in adults with asthma. Chest 2007;132:1871-5.

29. Borregaard N, Cowland JB. Granules of the human neutrophilic polymorphonuclear leukocyte. Blood 1997;89:3503-21.

30. Owen CA, Hu Z, Lopez-Otin C, Shapiro SD. Membrane-bound matrix metalloproteinase- 8 on activated polymorphonuclear cells is a potent, tissue inhibitor of metalloproteinase-resistant collagenase and serpinase. J Immunol 2004;172:7791-803.

31. Barnes P. Efficacy of inhaled corticosteroids in asthma. J Allergy Clin Immunol 1998;102:531-8. 


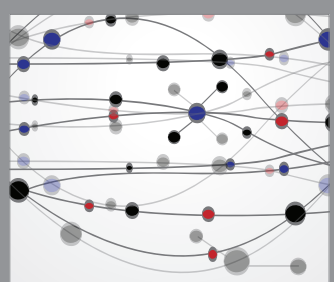

The Scientific World Journal
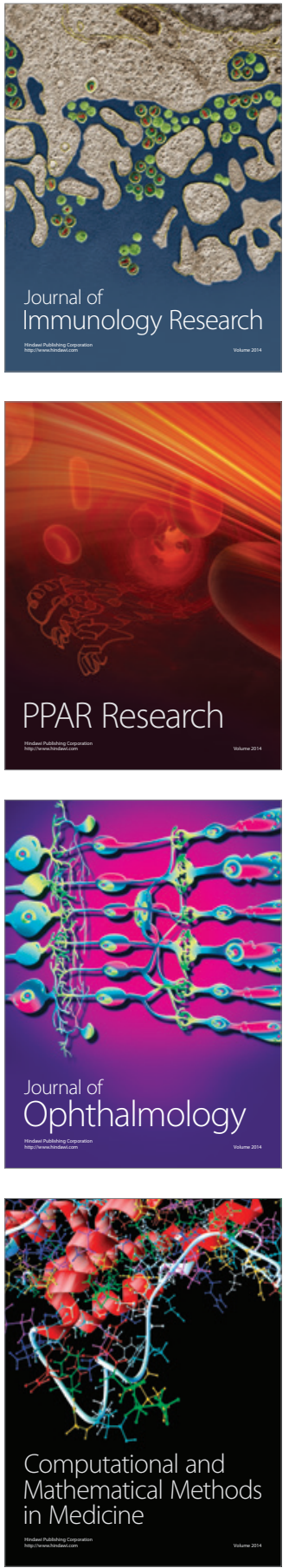

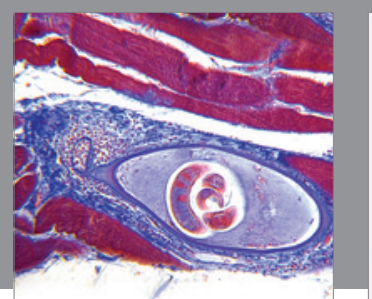

Gastroenterology Research and Practice

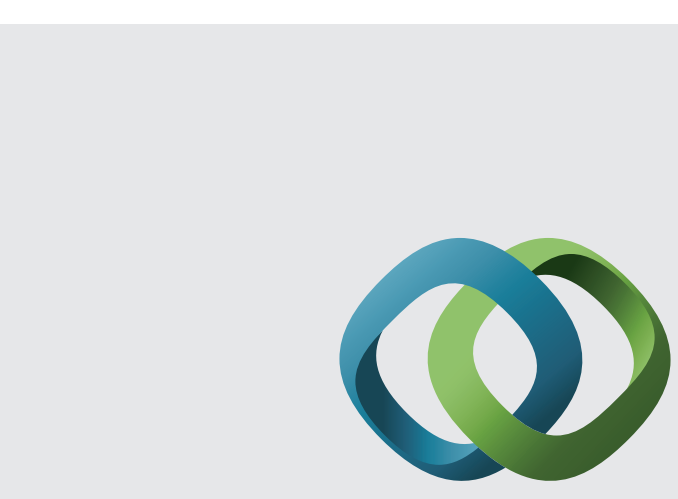

\section{Hindawi}

Submit your manuscripts at

http://www.hindawi.com
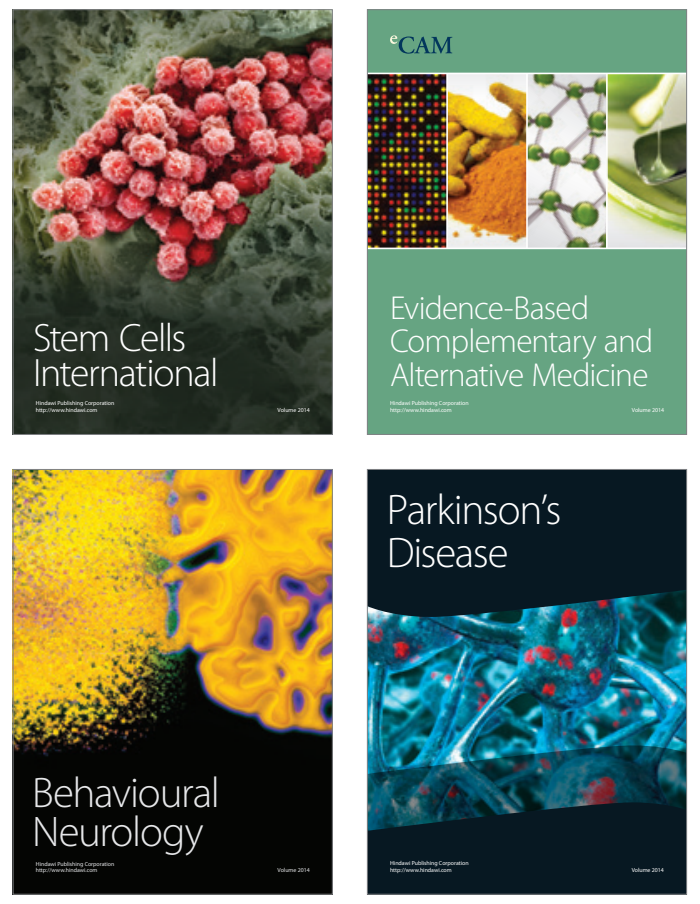
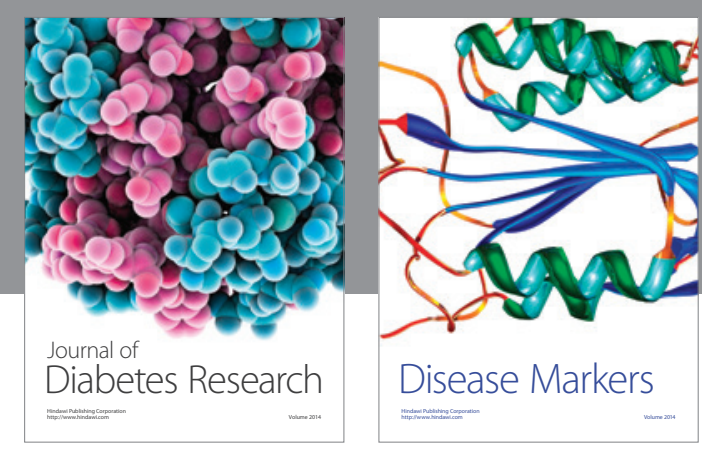

Disease Markers
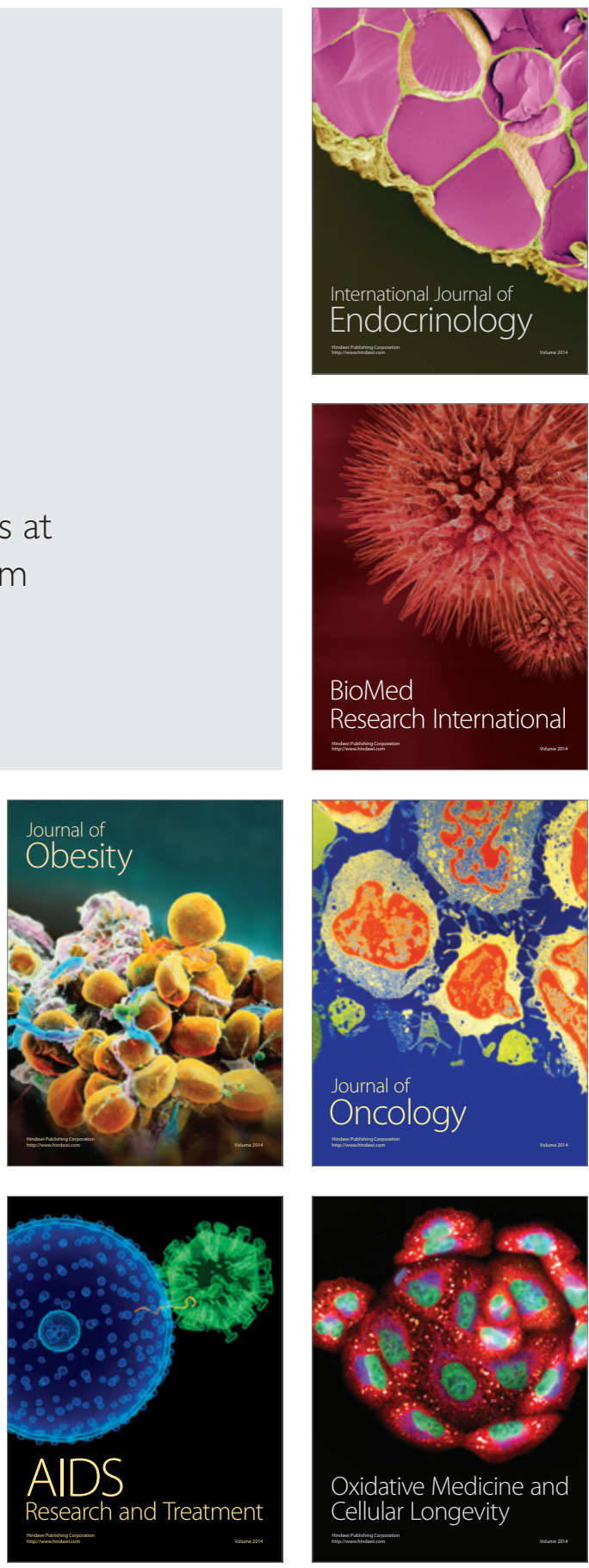